\title{
Language in the Ancient Near East
}


Russian State University

for the Humanities

Orientalia

etClassica

Труды Института восточных культур

и античности

Volume XXX/ 1

\section{Babel und Bibel 4/ 1}

Annual of Ancient Near Eastern, Old Testament, and Semitic Studies 


\title{
Language in \\ the Ancient Near East
}

\author{
Proceedings of the $53^{\mathrm{e}}$ \\ Rencontre Assyriologique Internationale \\ Vol. 1, Part 1
}

Edited by

L. Kogan, N. Koslova, S. LoEsov, And S. TishCHENKO

Published for

the Russian State University for the Humanities

by

EISENBRAUNS

Winona Lake, Indiana

2010 
Orientalia et Classica: Труды Института восточных кудьтур и античности. Выпуск XXX/1

Под редакиией Н. С. Смирнова

Вавимон и БибАия. 4/1

Редколлегия

А. Е. Коган, Н. В. Козлова, С. В. Аёзов, С. В. Тищенко

(c) Российский государственный гуманитарный университет, 2010

(C) Институт восточньтх культур и античности, 2010

ISBN 978-1-57506-195-5 (vol. 1)

ISBN 978-1-57506-196-2 (vol. 2)

ISBN 978-1-57506-167-2 (set)

ISSN 1938-5668

The paper used in this publication meets the minimum requirements of the American National Standard for Information Sciences-Permanence of Paper for Printed Library Materials, ANSI Z39.48-1984.@ ${ }^{\mathrm{TM}}$ 